Volume 3

Issue 2 -- Infectious Disease

Article 5

$4-22-2016$

\title{
Geodemographic Features of Human Blastomycosis in Eastern Wisconsin
}

Megan E. Huber

Dennis J. Baumgardner

Jessica J. F. Kram

Melissa A. Lemke

Follow this and additional works at: https://aah.org/jpcrr

Part of the Bacterial Infections and Mycoses Commons, Clinical Epidemiology Commons, Environmental Public Health Commons, Fungi Commons, and the Infectious Disease Commons

\section{Recommended Citation}

Huber ME, Baumgardner DJ, Kram JJ, Lemke MA. Geodemographic features of human blastomycosis in eastern Wisconsin. J Patient Cent Res Rev. 2016;3:90-98. doi: 10.17294/2330-0698.1251

Published quarterly by Midwest-based health system Advocate Aurora Health and indexed in PubMed Central, the Journal of Patient-Centered Research and Reviews (JPCRR) is an open access, peer-reviewed medical journal focused on disseminating scholarly works devoted to improving patient-centered care practices, health outcomes, and the patient experience. 


\title{
Geodemographic Features of Human Blastomycosis in Eastern Wisconsin
}

\author{
Megan E. Huber, ${ }^{1}$ Dennis J. Baumgardner, MD, ${ }^{2,3,4}$ Jessica J. F. Kram, MPH, ${ }^{2,3}$ \\ Melissa A. Lemke, MA $^{2,5}$ \\ ${ }^{1}$ Aurora Research Institute, Aurora Health Care, Milwaukee, WI \\ ${ }^{2}$ Center for Urban Population Health, Milwaukee, WI \\ ${ }^{3}$ Aurora University of Wisconsin Medical Group, Aurora Health Care, Milwaukee, WI \\ ${ }^{4}$ Department of Family Medicine and Community Health, University of Wisconsin School of Medicine and Public \\ Health, Madison, WI
}

${ }^{5}$ TRIUMPH Program, University of Wisconsin School of Medicine and Public Health, Milwaukee, WI
Purpose Blastomycosis is an endemic fungal infection. In rural northern Wisconsin, blastomycosis cases are associated with certain environmental features including close proximity to waterways. Other studies have associated blastomycosis with particular soil chemicals. However, blastomycosis also occurs in urban and suburban regions. We explored the geodemographic associations of blastomycosis cases in the more urban/suburban landscape of eastern Wisconsin.

Methods We conducted a retrospective study of 193 laboratory-identified blastomycosis cases in a single eastern Wisconsin health system, 2007-2015. Controls were 250 randomly selected cases of communitydiagnosed pneumonia from a similar time period. Geographic features of home addresses were explored using Google Maps. Categorical variables were analyzed with chi-square or Fisher's exact tests and continuous variables by two-sample t-tests. Stepwise regression followed by binary logistic regression was used for multivariable analysis.

Results $\quad$ Compared to pneumonia cases, blastomycosis cases were younger (47.7 vs. 55.3 years) and more likely to be male $(67.9 \%$ vs. $45.6 \%)$, nonwhite $(23.2 \%$ vs. $9.7 \%)$ and machinists, automobile workers/ mechanics or construction workers $(32.7 \%$ vs. $7.2 \%)$; $<0.001$ for all. These relationships remained significant on multivariable modeling. Case home sites, compared to controls, were more likely to have water frontage, $(17.6 \%$ vs. $7.5 \%, P=0.004)$, be $>0.5$ acres $(30.4 \%$ vs. $14.2 \%, P=0.0002)$, be $<0.25$ miles from an automobile repair facility or junkyard (35.9\% vs. 19.4\%, $\mathrm{P}=0.0005)$, and be $<0.1$ miles from a park, forest or farm field $(54.9 \%$ vs. $39.6 \%, \mathrm{P}=0.002)$. Only the latter association remained on multivariable analysis.

Conclusions Eastern Wisconsin blastomycosis case subjects were younger, more often male and more likely to live near parks/forests/fields. Novel associations of blastomycosis cases with machinery- and automobile-related occupations and/or facilities should be further explored. (J Patient Cent Res Rev. 2016;3:90-98.)

Keywords Blastomyces dermatitidis; fungal ecology; mycoses; environmental exposure; blastomycosis

Blastomycosis is a potentially serious systemic and cutaneous fungal infection endemic to eastern North America (and parts of India and Africa). ${ }^{1}$ Disease is acquired from the environment by inhalation of spores of the etiologic fungi Blastomyces dermatitdis or Blastomyces gilchristii. ${ }^{2}$ Blastomycosis incidence rates are particularly high in Wisconsin compared to

Correspondence: Dennis J. Baumgardner, MD, Aurora Sinai Medical Center, 1020 N. 12th Street, \#4180, Milwaukee, WI, 53233, T: 414-219-5191, F: 414-219-3116, Email: dennis.baumgardner@aurora.org the rest of the nation. ${ }^{3}$ While reports are emerging from lesser endemic portions of the state, ${ }^{4,5}$ most epidemiologic investigations of sporadic and outbreak cases have focused on rural northern and central Wisconsin. ${ }^{6-17}$ Despite generally lower incidence rates of blastomycosis in more urban eastern and southeastern Wisconsin counties, case numbers often meet or exceed those from their rural Wisconsin counterparts. For example, recent annual incidence rates for rural Vilas County, Wisconsin $(27 / 100,000)^{10}$ equate to 5.5 cases per year from this county. Whereas a conservative estimate of blastomycosis rate in 
Milwaukee County $(1 / 100,000)^{5}$ equates to 9.5 cases per year, and compares well to average endemic area rates in the United States (approximately 1-2 cases per 100,000 people per year). ${ }^{18}$

The precise ecologic niche of Blastomyces species remains incompletely defined. Compared to other soil bacteria and fungi, these fungal species are poorly competitive in the environment; however, their ability to survive harsh conditions and rapid environmental change may enable them to survive and even thrive for certain periods of time..$^{9,11,19-22}$ Blastomyces fungi tolerate a wide range of temperatures and periods of relative drought. ${ }^{19,20}$ Antecedent weather conditions appear to partially predict subsequent blastomycosis cases in at least certain regions. ${ }^{9-11,23}$ In addition, soil levels of certain chemicals such as ammonia, ${ }^{21}$ copper and mercury ${ }^{3}$ may be important to the microecology of Blastomyces.

As summarized elsewhere in this issue ${ }^{24}$ - although some have demurred ${ }^{25,26}$ — there appears to be good circumstantial evidence that blastomycosis can be acquired on one's home property. ${ }^{27-31}$ For these reasons, we used home addresses of blastomycosis cases to explore environmental associations of this disease in our previous Wisconsin studies. In one such study, home addresses were compared to certain geographic features utilizing a geographic information system. ${ }^{12}$ In other studies the home sites were personally visited, however, observations of some portions of properties and the ability to very accurately measure distances to the nearest feature of interest were limited by observation from the nearest public access. ${ }^{5,13-16}$ Another recent study of blastomycosis endemic regions nationwide used only county level variables. ${ }^{3}$ Thus, important geographic features or sources of chemical exposure on or in close proximity to the home sites of blastomycosis cases could have escaped observation.

The aim of this study was to explore geodemographic associations among home properties of blastomycosis cases in predominantly urban and suburban eastern Wisconsin, utilizing a group of community-diagnosed pneumonia cases as controls.

\section{METHODS}

\section{Setting}

Data for this study was drawn from a large, integrated health system that includes 15 hospitals and 159 outpatient clinics throughout eastern Wisconsin and extreme northeastern Illinois. Geologically, eastern Wisconsin consists of glacial lowlands and plains, interspersed with ridges and other glacial surface features. The predominant bedrock is limestone. ${ }^{32}$ The majority of the region is farmland, with an increasing minority of forest cover. ${ }^{33}$ The area contains the majority of the state's urban and suburban population. The largest county, Milwaukee County, is located in southeastern Wisconsin and has a 2014 U.S. Census population estimate of 956,406 .

\section{Subject Selection}

For this retrospective review of electronic medical records, blastomycosis cases from July 2007 to July $2015(\mathrm{~N}=193)$ were obtained from a comprehensive database of laboratory-diagnosed individuals with blastomycosis housed at our institution's affiliated laboratory.

Control subjects were obtained from a previously assembled cohort of 250 randomly selected adult patients with community-acquired pneumonia (CAP) diagnosed by primary care clinicians in an outpatient facility from October 2006 to July 2013. Patients were identified by ICD-9 diagnostic codes 480-486 (and subsets) with the following diagnoses excluded from the study: cancer, bronchiectasis, blood disorders, tuberculosis, HIV/AIDS, tracheostomy/ventilator dependence and pregnancy. Details of this cohort are described in detail elsewhere in this issue. ${ }^{34}$

All activities were reviewed and approved by the local institutional review board.

\section{Data Sources}

Case and control subjects were reviewed in the electronic medical records. Basic demographic data were collected, including age, gender, race/ethnicity, occupation and street address. When multiple street addresses or occupations were available, every attempt was made to use the one most closely associated with the occurrence of the index illness. Google Maps' map view and satellite imagery ("Earth View") were used to explore the case or control home site and nearby environments (Google Maps/Google Earth Imagery, 2015). We chose a novel approach of utilizing Google Maps for viewing and measurement of nearby features, thereby avoiding the difficulties in observation 
Table 1. Descriptions of racial/ethnic, occupational and surface geographical and geological variables used in univariable analysis of blastomycosis cases in eastern Wisconsin

\begin{tabular}{|c|c|c|}
\hline Variable & Definition/Description & Categorical unit(s) \\
\hline Race/ethnicity & Self-identification in electronic medical record & $\begin{array}{l}\text { White } \\
\text { Black } \\
\text { Native American } \\
\text { Asian/Pacific Islander } \\
\text { Other } \\
\text { Hispanic/Latino } \\
\text { Two or more }\end{array}$ \\
\hline Occupation & $\begin{array}{l}\text { Self-identification in electronic medical record or public description of } \\
\text { place of business listed under "occupation" }\end{array}$ & $\begin{array}{l}\text { Machinist/autoworker or repair/ } \\
\text { construction } \\
\text { Trucker/postal delivery } \\
\text { Machinery/auto-related such as } \\
\text { mechanical engineer or auto sales } \\
\text { Teacher } \\
\text { Other - various }\end{array}$ \\
\hline $\begin{array}{l}\text { Water } \\
\text { distance }\end{array}$ & $\begin{array}{l}\text { Linear distance calculated from home site to nearest body of water } \\
\text { (see below) }\end{array}$ & $\begin{array}{l}\text { None within } 1.5 \mathrm{mi} \\
\leq 0.10 \mathrm{mi} \\
0.10 \mathrm{mi}<\text { distance } \leq 0.25 \mathrm{mi}\end{array}$ \\
\hline $\begin{array}{l}\text { Park } \\
\text { distance }\end{array}$ & $\begin{array}{l}\text { Linear distance calculated from home site to edge of nearest park } \\
\text { boundary designated on Google Maps (empty lots not included) }\end{array}$ & $\begin{array}{l}0.25 \mathrm{mi}<\text { distance } \leq 0.50 \mathrm{mi} \\
0.50 \mathrm{mi}<\text { distance } \leq 1.0 \mathrm{mi}\end{array}$ \\
\hline $\begin{array}{l}\text { Auto business } \\
\text { distance }\end{array}$ & $\begin{array}{l}\text { Linear distance calculated from home site to nearest auto-related } \\
\text { business (see below) }\end{array}$ & $>1.0 \mathrm{mi}$ \\
\hline $\begin{array}{l}\text { School } \\
\text { distance }\end{array}$ & $\begin{array}{l}\text { Linear distance calculated from home site to edge of nearest } \\
\text { elementary, middle, high school or college property }\end{array}$ & \\
\hline $\begin{array}{l}\text { Worship } \\
\text { distance }\end{array}$ & $\begin{array}{l}\text { Linear distance calculated from home site to edge of nearest church, } \\
\text { temple, synagogue, mosque or other community center for religious } \\
\text { faith property }\end{array}$ & \\
\hline Water type & $\begin{array}{l}\text { Lakes and rivers only coded when specific body of water suggested } \\
\text { such (ex: Lake Michigan, Fox River); otherwise coded as ponds } \\
\text { and streams, respectively } \\
\text { No wetlands were designated by Google, therefore none were coded }\end{array}$ & $\begin{array}{l}\text { None within } 1.5 \mathrm{mi} \\
\text { Lake } \\
\text { River } \\
\text { Stream/creek } \\
\text { Wetland } \\
\text { Pond }\end{array}$ \\
\hline $\begin{array}{l}\text { Water } \\
\text { frontage }\end{array}$ & $\begin{array}{l}\text { Visually obvious property border abuts body of water (incl. small } \\
\text { ponds engulfed by property) }\end{array}$ & $\begin{array}{l}\text { Present } \\
\text { Absent }\end{array}$ \\
\hline Park type* & $\begin{array}{l}\text { Parks with few, if any, trees and/or a distinguishable playing field } \\
\text { (baseball, soccer, etc.) coded as "1" } \\
\text { Parks with trees (of any type) coded as "2" unless trees so thick as } \\
\text { to block bird's eye view of grass, in which case coded as forest } \\
\text { Parks with any water frontage/engulfed water feature (as physically } \\
\text { seen in Earth View or as designated by light blue in "map" view) } \\
\text { coded as " } 3 \text { " }\end{array}$ & $\begin{array}{l}\text { None within } 1.5 \mathrm{mi} \\
\text { Grass/baseball/school } \\
\text { Trees and grass } \\
\text { Park with pond/stream/other water } \\
\text { Other }\end{array}$ \\
\hline $\begin{array}{l}\text { Auto business } \\
\text { type }\end{array}$ & $\begin{array}{l}\text { Designated according to Google summary of type of auto-related } \\
\text { business }\end{array}$ & $\begin{array}{l}\text { Codes included: "auto repair," "car } \\
\text { repair," "auto body," "mechanic," } \\
\text { "used car dealer," "car dealer," } \\
\text { "salvage," "junkyard," "car wash" } \\
\text { Other auto-related businesses }\end{array}$ \\
\hline Street type & Street/road/highway designated in subject street address & $\begin{array}{l}\text { Dirt/unpaved } \\
\text { Cul-de-sac } \\
\text { Neighborhood street } \\
\text { Busy street/boulevard } \\
\text { County/state highway } \\
\text { U.S. interstate highway }\end{array}$ \\
\hline
\end{tabular}


Table 1 (cont). Descriptions of racial/ethnic, occupational and surface geographical and geological variables used in univariable analysis of blastomycosis cases in eastern Wisconsin

\begin{tabular}{|c|c|c|}
\hline Variable & Definition/Description & Categorical unit(s) \\
\hline $\begin{array}{l}\text { Neighborhood } \\
\text { type }\end{array}$ & $\begin{array}{l}\text { Determined by } 2010 \text { U.S. Census maps (lines and colorings denoted } \\
\text { in right column refer to these maps) }\end{array}$ & $\begin{array}{l}\text { Urban — within green lines and } \\
\text { colored areas (no patterning) } \\
\text { Suburban - within colored areas } \\
\text { (outside green lines) or within green } \\
\text { lines and outside colored areas } \\
\text { (patterning) } \\
\text { Rural — within township but outside } \\
\text { colored areas and green lines } \\
\text { Farm — without all boundaries }\end{array}$ \\
\hline House type & $\begin{array}{l}\text { Assumed "house" unless shown otherwise by: address indicating } \\
\text { apartment/lot number; residence within mobile home community } \\
\text { area; two sets of street numbers/doorbells indicative of a duplex } \\
\text { living arrangement }\end{array}$ & $\begin{array}{l}\text { House } \\
\text { Mobile home } \\
\text { Apartment } \\
\text { Duplex }\end{array}$ \\
\hline Property size & $\begin{array}{l}\text { Rough rectangular measurements of property boundaries obtained, } \\
\text { then converted into acreage }\end{array}$ & $\begin{array}{l}<0.5 \text { acres } \\
<2.0 \text { acres } \\
>2.0 \text { acres }\end{array}$ \\
\hline Yard type & Designated by type of yard that covers majority of the property & $\begin{array}{l}\text { Grass } \\
\text { Grass and deciduous trees } \\
\text { Grass and coniferous trees } \\
\text { Grass and mixed trees } \\
\text { Pavement } \\
\text { Farmland } \\
\text { Forested } \\
\text { Bare } \\
\text { Other }\end{array}$ \\
\hline Forest nearby & $\begin{array}{l}\text { A group of } 10 \text { or more trees that grow close enough to obscure a } \\
\text { bird's eye view of the ground beneath; coded as "present" when } \\
\text { forest is within } 0.10 \mathrm{mi}\end{array}$ & $\begin{array}{l}\text { Present } \\
\text { Absent }\end{array}$ \\
\hline Farm nearby & $\begin{array}{l}\text { Patch of land (field) greater than } 0.5 \text { acres that appears to grow } \\
\text { crops or that is not forested, grassed or cultivated for reasons } \\
\text { beyond creating produce; coded as "present" when field is within } \\
0.10 \text { mi. (Note: grassy, large, open areas coded as park, not farm.) }\end{array}$ & $\begin{array}{l}\text { Present } \\
\text { Absent }\end{array}$ \\
\hline
\end{tabular}

*On the "map" view option of Google Maps, parks are designated in shades of green.

encountered in previous studies. ${ }^{3,5,12-16}$ Linear distances were calculated via map view. Variables of interest were explored as defined and summarized in Table 1. Nearby natural features were explored for every case and control subject. For nearby businesses, every type of business was explored for the first 35 blastomycosis cases. For the remainder of cases, and all of the controls, business types rarely or not found in the first 35 blastomycosis cases were not sought.

\section{Statistical Analysis}

Minitab $^{\circledR}$ statistical software (State College, PA) was used for data analysis. Basic descriptive and summary statistics were calculated. Categorical data were analyzed using chi-square tests with Yates' correction. Continuous variables were analyzed using two-sample t-tests.
Stepwise regression (for significant predictors) followed by binary logistic regression was used for multivariable analysis of blastomycosis cases versus CAP controls for variables found statistically significant on univariable analysis. Odds ratios were calculated. Significance of associations was defined by P-value less than 0.05 . Case and control home addresses by Wisconsin ZIP code were compiled into maps using ArcGIS 10 geographic information system software (Esri, Redlands, CA).

\section{RESULTS}

From July 2007 to July 2015, 193 laboratory-confirmed blastomycosis cases were identified. The calculated annual incidence rate based on this eastern Wisconsin health system's patient population (i.e. 1.2 million distinct patients per year) is 2.01 cases/100,000 persons, 
which is consistent with previous estimations. ${ }^{5}$ Of note, this is not a community-based population incidence rate.

Compared to CAP controls, adult blastomycosis cases were significantly younger (47.7 vs. 55.3 years, $\mathrm{P}<0.0001)$ and more likely to be male $(67.9 \%$ vs. $45.6 \%, \mathrm{P}<0.0001)$. Blastomycosis cases differed from controls regarding distribution of race/ethnicity (cases: white $77 \%$, black $11 \%$, Hispanic $7 \%$, other $5 \%$; vs. controls: white $90 \%$, black 5\%, Hispanic 5\%) in that cases were more apt than controls to be black $(\mathrm{P}=0.024)$ or nonwhite $(\mathrm{P}=0.0004)$.

Interpretable occupations were listed for 85 cases and 152 controls. Cases were more likely than controls to be machinists, automobile workers/mechanics or construction workers than all other occupations (32.7\% vs. $7.2 \%, \mathrm{P}<0.0001)$. Additionally, cases were more likely than controls to have one of the following occupations - machinist, automobile worker/ mechanic, construction worker, postal or truck driver, and machinery- or auto-related occupation such as mechanical engineer or automobile sales - than any other occupation $(61.2 \%$ vs. $32.9 \%, \mathrm{P}<0.0001)$.

A total of 159 cases and 226 controls had addresses that were not post office box numbers and were locatable on Google Maps. Most subjects lived in neighborhoods technically classified as urban or suburban. The breakdown of this distribution did not differ between blastomycosis subjects and CAP controls (blastomycosis: urban $82 \%$, suburban $8 \%$, rural $8 \%$, farm $2 \%$ vs. controls: urban $81 \%$, suburban $9 \%$, rural 5\%, farm 5\%). A number of geographic and surface geologic differences, at various distances, were seen between cases and controls when these variables were subjected to univariable analysis (Table 2). Interestingly, home sites of control subjects were significantly more likely to be within a quarter-mile of a waterway than case home sites ( $54.4 \%$ vs. $43.4 \%, \mathrm{P}=0.04)$; however, cases were significantly more likely than controls to have water frontage $(17.6 \%$ vs. $7.5 \%, \mathrm{P}=0.004)$. Cases were more likely than controls to be in close proximity to forests, farm fields, parks, auto-related businesses and places of worship.

Following multivariable modeling, significant remaining predictors of blastomycosis cases, as compared to CAP controls, included male sex, younger age, nonwhite race/ethnicity, occupation in machineryor auto-related businesses or as postal or freight drivers (as compared to all other occupations), and home sites within 0.1 miles of a park, forest or farm field (Table 3).

Figure 1 illustrates the geographic distribution of Wisconsin-only case and control subjects.

Table 2. Significant geographic or surface geologic predictors on univariable modeling: blastomycosis cases vs. CAP controls

\begin{tabular}{|c|c|c|c|}
\hline Characteristic* & Cases & Controls & $P$ \\
\hline Water frontage & $17.6 \%(n=28)$ & $7.5 \%(n=17)$ & 0.004 \\
\hline Forest (within $0.10 \mathrm{mi}$ ) & $37.1 \%(n=59)$ & $20.8 \%(n=47)$ & 0.0006 \\
\hline Farm field (within $0.10 \mathrm{mi}$ ) & $30.2 \%(n=48)$ & $15.9 \%(n=36)$ & 0.001 \\
\hline Property size (>0.5 acres) & $30.4 \%(n=48)$ & $14.2 \%(n=32)$ & 0.0002 \\
\hline Property size (>2 acres) & $20.9 \%(n=33)$ & $6.2 \%(n=14)$ & $<0.0001$ \\
\hline Within $0.1 \mathrm{mi}$ of auto business & $14.5 \%(n=23)$ & $3.5 \%(n=8)$ & 0.0002 \\
\hline Within $0.25 \mathrm{mi}$ of auto business ${ }^{\dagger}$ & $35.9 \%(n=57)$ & $19.4 \%(n=44)$ & 0.0005 \\
\hline Within $0.1 \mathrm{mi}$ of park & $32.7 \%(n=52)$ & $22.6 \%(n=51)$ & 0.036 \\
\hline Within $0.25 \mathrm{mi}$ of worship & $44.7 \%(n=71)$ & $33.2 \%(n=75)$ & 0.030 \\
\hline Within $0.1 \mathrm{mi}$ of park/forest/farm & $54.9 \%(n=106)$ & $39.6 \%(n=99)$ & 0.002 \\
\hline Machinist/autoworker/construction & $31.8 \%(n=27)$ & $7.2 \%(n=11)$ & $<0.0001$ \\
\hline $\begin{array}{l}\text { Above occupation, other machinery/auto-related } \\
\text { employment, or postal/truck driver }\end{array}$ & $61.2 \%(n=52)$ & $32.9 \%(n=50)$ & $<0.0001$ \\
\hline
\end{tabular}

*See Table 1 for characteristic descriptions/definitions.

${ }^{+}$Distribution of nearby automobile-related businesses, as delineated in Table 1, did not differ between cases and controls (data not shown).

$C A P$, community-acquired pneumonia. 
Table 3. Significant predictors on multivariable modeling: blastomycosis cases vs. CAP controls

\begin{tabular}{lcc}
\hline Predictor & $\boldsymbol{P}$ & $\begin{array}{c}\text { Odds } \\
\text { ratio }\end{array}$ \\
\hline Male & 0.001 & 3.44 \\
Age & $<0.0001$ & $0.95^{*}$ \\
Nonwhite race & $<0.0001$ & 6.25 \\
Within 0.1 mi of park/forest/farm & 0.011 & 2.38 \\
Machinist/autoworker/construction & $<0.0001$ & 6.89 \\
$\begin{array}{l}\text { Above occupation, other machinery/ } \\
\text { auto-related employment, or } \\
\text { postal/truck driver }\end{array}$ & 0.03 & 2.86 \\
\hline
\end{tabular}

*Risk decreases $5 \%$ for every additional year of age.

tWhen placed in multivariable model instead of the variable listed immediately above, significance and odds ratios of other items were not significantly affected.

CAP, community-acquired pneumonia.

Blastomycosis cases were more widely dispersed throughout the eastern Wisconsin catchment area of our integrated health system than CAP controls, whereas the latter were concentrated around the urban centers of eastern Wisconsin. Overall, 37.1\% of case and $44.0 \%$ of control home addresses were within the urban counties of Milwaukee and Waukesha, an insignificant difference $(\mathrm{P}=0.18)$.

\section{DISCUSSION}

This epidemiologic survey revealed several important geodemographic associations between patients with laboratory-diagnosed blastomycosis and those diagnosed with CAP. Many of these associations were anticipated, a few were not. Male predominance of blastomycosis cases, and a normal distribution of age around middle-aged adults, have been recognized in many endemic regions for decades ${ }^{1}$ and in Northern Wisconsin over the past 35 years. ${ }^{10}$ Among adults, CAP is considered a disease of the elderly with equal sex and racial distribution, although good community-based data is lacking. ${ }^{35,36}$ Prior studies have inconsistently suggested an increased incidence of blastomycosis in blacks and certain other nonwhite persons, ${ }^{37,38}$ and higher age-adjusted mortality rates in these groups. ${ }^{39}$ Recent studies have suggested differing clinical features of blastomycosis among different human genetic and ethnic groups. ${ }^{8,40}$
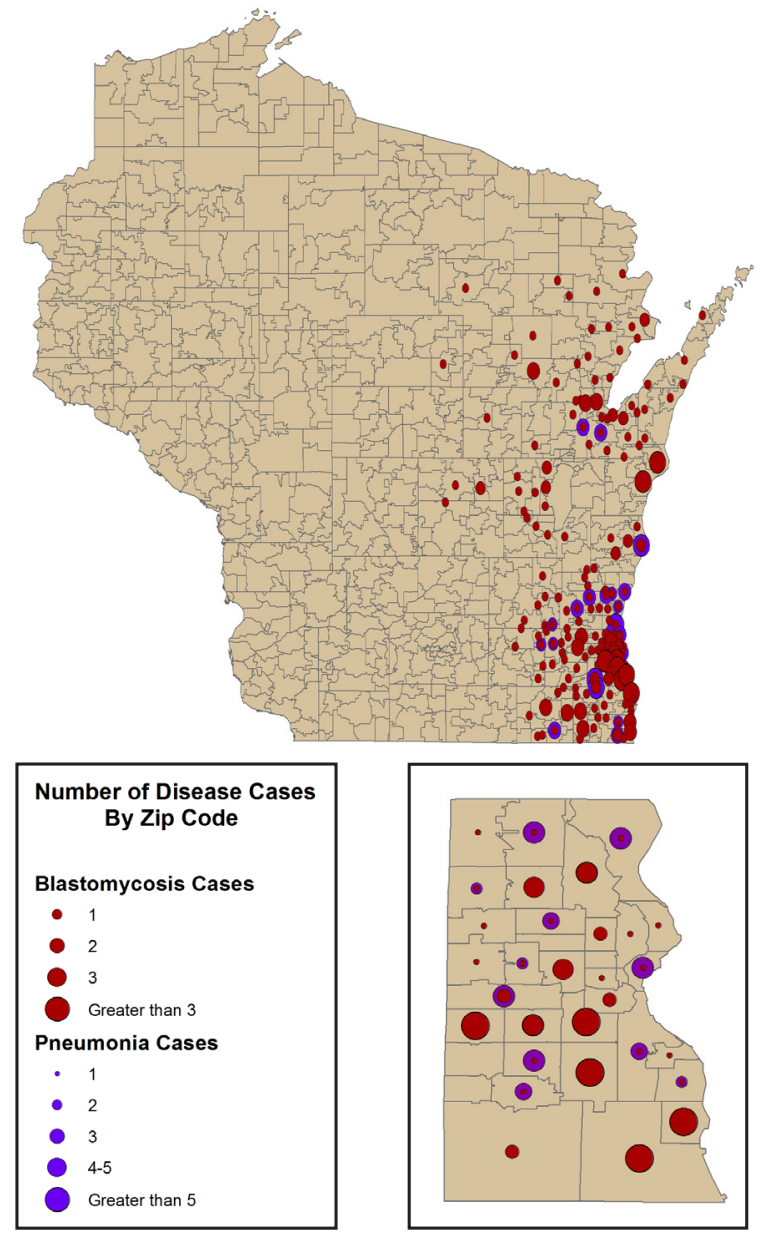

Figure 1. Blastomycosis versus pneumonia cases, Wisconsin 2007-2015. Maps of the geographic distribution of blastomycosis cases and control subjects with community-acquired pneumonia in eastern Wisconsin and Milwaukee County (inset). Blastomycosis cases were more widely dispersed throughout the eastern Wisconsin catchment area of the studied integrated health system than pneumonia controls.

In Vilas County, in rural northern Wisconsin, human and dog blastomycosis cases were associated with close proximity to waterways, ${ }^{13,16}$ perhaps most especially lower elevation lakes. ${ }^{12}$ In urban Milwaukee County, blastomycosis cases were most commonly associated with open inland water sites, followed by the Lake Michigan shoreline, compared to highly organized and controlled inland waterways. ${ }^{5}$ The present study reveals a paradox, on univariable analysis, whereby home sites of control subjects were more apt to be within a quartermile of a waterway compared to blastomycosis cases, whereas blastomycosis case home properties were more apt to have water frontage. The eastern Wisconsin 
location of this study, particularly with respect to the highly urbanized areas (where CAP controls were clustered), includes the Lake Michigan shoreline as a dominant geographic feature. This is not true in Vilas County. Perhaps the housing layouts for our selected controls are not geographically random such that the control group has a predominance of quarter-mile waterway proximity due to population density. The association with water frontage in our present study is reminiscent of the association of dog blastomycosis cases with very close waterway proximity in a previous study of Eagle River, a municipality in rural northern Wisconsin. ${ }^{15}$ Property water frontage or very close waterway proximity that would invite human or animal contact with the shoreline may be paramount.

Certainly, many outbreak and endemic cases of blastomycosis are in or near forestation (or rural areas including farms). ${ }^{19}$ This is true involving Vilas County, ${ }^{16,31}$ however, statistical association of forests with cases versus controls was not seen, perhaps because of the extensive forestation in the region. ${ }^{13}$ In the present study, multivariable analysis revealed significantly increased odds of a blastomycosis home site being in close proximity to a park, forest or farm field. Perhaps these features, often considered to be more typical of rural areas but sometimes found in association with urban and suburban areas, provide important ecological habitat for Blastomyces to persist or temporarily thrive such that spores of the fungus blow into or propagate in the case property, ${ }_{10,11,21}$ or the resident is exposed to the fungus during a short walk or soil-disturbing activity. Overall, the distribution of blastomycosis case home sites in eastern Wisconsin in our study matched closely with a map of the predicted geographic distribution of cases in this region based on ecologic niche modeling. ${ }^{41}$

Our study has shown an association between blastomycosis and occupation as a machinist, autoworker, construction worker, truck driver or in other machinery/auto-related businesses on both univariable and multivariable analyses. Residence in close proximity to auto-related businesses was associated on univariable analysis only. As reviewed elsewhere in this issue,,${ }^{24}$ many studies, but not all, ${ }^{42}$ found outdoor occupations made up a minority of blastomycosis cases. There have been reports of blastomycosis cases in autoworkers based on short case series or case studies, ${ }^{37,43-45}$ but no systematic investigation of this connection. Whether auto-related businesses afford opportunities for workplace exposure to Blastomyces, or whether this association simply reflects persons who disproportionately encounter the fungus during home or recreational activities, is unclear.

Based on county level data, blastomycosis hospitalization was associated with increased levels of mercury and decreased levels of copper in the soil. ${ }^{3}$ One recent study documented significant levels of heavy metal contamination within auto repair workshops (likely containing dirt floors). However, this study was conducted in Nigeria, where regulations are substantially different than in the United States. ${ }^{46}$ In the early 1990s, the potential for substantial heavy metal and both organic and inorganic chemical pollution surrounding automobile facilities in the United States was recognized. ${ }^{47}$ Concern for accidental spills remains a concern. ${ }^{48}$

Blastomyces has been shown to tolerate a variety of harsh substances. ${ }^{19,21,22}$ One can speculate that human or machinery "tracking," or "washout" of heavy metals or chemicals onto nearby soil (adjacent to parking lots, etc.), could lead to a microenvironment that favors growth of Blastomyces. Regardless, occupational risk for blastomycosis, beyond that of obvious soildisturbing activities, should not be discounted. A 2009 study of 112 blastomycosis patients and 118 neighborhood controls revealed that having a coworker with blastomycosis was an independent risk factor for the disease. ${ }^{42}$ Further investigation of associated occupations seems warranted.

\section{Study Limitations}

The retrospective nature of the present study has the inherent limitation of reliance on data collected for clinical or registration purposes being complete and accurate. This was likely only significantly limiting for data regarding occupation. Additionally, important variables may not have been explored. This study primarily investigated home sites of blastomycosis cases. The authors attempted to use the home address most closely associated with the occurrence of the index illness, however, it is possible that certain addresses did not reflect the location at the time of disease exposure or occurrence. Such discrepancy could have occurred for both case and control subjects, but presumably to a limited extent. 
One might suggest that observation of home sites using Google Maps is no substitute for personally visiting the home site and interviewing the subject, and that features observed at the time of acquisition of the particular satellite map may have differed from that at the time of case exposure or occurrence, perhaps due to temporal or seasonal differences. Some important nearby businesses or other built environmental features may not have been observed on existing maps. It was not possible to make a direct link between cases and occupations at particular facilities close to (or distant from) their homes. Similarly, we were unable to determine if particular auto-related businesses were outdoor or open facilities (i.e. exposed to the elements). Certainly, these are all valid concerns. Nonetheless, with limited resources, this approach was an inexpensive way to objectively view and measure the surface features of the involved home sites.

\section{CONCLUSIONS}

In predominantly urban/suburban eastern Wisconsin, blastomycosis occurs less frequently than in rural northern Wisconsin, yet the disease burden is not trivial. Having nearby natural, open or nondomicile features such as park land, forests or fields may increase the risk of a home site being associated with blastomycosis. Additional epidemiologic and environmental studies (hampered, of course, by the difficulty in isolating Blastomyces from the environment ${ }^{30}$ ) are required to determine if automobile/machinery-related occupations or nearby businesses increase the risk for acquisition of blastomycosis. Further elucidation of the environmental determinants of Blastomyces distribution and propagation could lead to more specific preventive recommendations.

\section{Patient-Friendly Recap}

- Blastomycosis is a fungal infection, primarily of the lungs.

- In rural Wisconsin, it is likely most often acquired by people living near waterways.

- The authors identified cases of blastomycosis contracted by people living in more urbanized areas of the state and studied the landscape surrounding their homes.

- They found that homes near parks, forested lots or urban/suburban fields as well as employment by machinery- or auto-related businesses may increase likelihood of blastomycosis occurrence.

\section{Acknowledgments}

The authors would like to acknowledge Julie Prabucki, MT(ASCP), for identification of laboratory-confirmed blastomycosis cases, Kiley B. Vander Wyst, MPH, for compilation of control subject data, and Khalyne T. Johnson, MD, for preliminary analysis of geographic distribution of cases.

\section{Conflicts of Interest}

None.

\section{References}

1. Bradsher RW Jr. Blastomycosis. In: Bennett JE, Dolin R, Blaser MJ (eds). Mandell, Douglas, and Bennett's Principles and Practice of Infectious Diseases, Eighth Edition. Philadelphia, PA: Elsevier Saunders, 2015, pp. 2963-73.e2.

2. Brown EM, McTaggart LR, Zhang SX, Low De, Stevens DA, Richardson SE. Phylogenetic analysis reveals a cryptic species Blastomyces gilchristii, sp. nov. within the human pathogenic fungus Blastomyces dermatitidis. PLoS One. 2013;8:e59237. CrossRef

3. Seitz AE, Adjemian J, Steiner CA, Prevots DR. Spatial epidemiology of blastomycosis hospitalizations: detecting clusters and identifying environmental risk factors. Med Mycol. 2015;53:447-54. CrossRef

4. Pfaff BL, Agger WA, Volk TJ. Blastomycosis diagnosed in a nonhyperendemic area. WMJ. 2014;113:11-8.

5. Baumgardner DJ, Knavel E, Steber D, Swain G. Geographic distribution of human blastomycosis cases in Milwaukee, Wisconsin, USA: association with urban watersheds. Mycopathologia. 2006;161:275-82. CrossRef

6. Klein BS, Vergeront JM, Weeks RJ, et al. Isolation of Blastomyces dermatitidis in soil associated with a large outbreak of blastomycosis in Wisconsin. $N$ Engl J Med. 1986;314: 529-34. CrossRef

7. Klein BS, Vergeront JM, DiSalvo AF, Kaufman L, Davis JP. Two outbreaks of blastomycosis along rivers in Wisconsin. Isolation of Blastomyces dermatitidis from riverbank soil and evidence of its transmission along waterways. Am Rev Respir Dis. 1987;136:1333-8. CrossRef

8. Roy M, Benedict K, Deak E, et al. A large community outbreak of blastomycosis in Wisconsin with geographic and ethnic clustering. Clin Infect Dis. 2013;57:655-62. CrossRef

9. Proctor ME, Klein BS, Jones JM, Davis JP. Cluster of pulmonary blastomycosis in a rural community: evidence for multiple high-risk environmental foci following a sustained period of diminished precipitation. Mycopathologia. 2002;153:113-20. $\underline{\text { CrossRef }}$

10. Baumgardner DJ, Bernhard KA, Egan G. Pulmonary blastomycosis in Vilas County, Wisconsin: weather, exposures and symptoms. J Patient Cent Res Rev. 2015;2:25-33. CrossRef

11. Baumgardner DJ, Paretsky DP, Baeseman ZJ, Schreiber A. Effects of season and weather on blastomycosis in dogs: Northern Wisconsin, USA. Med Mycol. 2011;49:49-55. CrossRef

12. Baumgardner DJ, Steber D, Glazier R, etal. Geographic information system analysis of blastomycosis in northern Wisconsin, USA: waterways and soil. Med Mycol. 2005;43:117-25. CrossRef 
13. Baumgardner DJ, Paretsky DP, Yopp AC. The epidemiology of blastomycosis in dogs: north central Wisconsin, USA. $J$ Med Vet Mycol. 1995;33:171-6. CrossRef

14. Baumgardner DJ, Brockman K. Epidemiology of human blastomycosis in Vilas County, Wisconsin. II: 1991-1996. WMJ. 1998;97:44-7.

15. Baumgardner DJ, Turkal NW, Paretsky DP. Blastomycosis in dogs: a fifteen-year survey in a very highly endemic area near Eagle River, Wisconsin. Wild Environ Med. 1996;7:1-8. CrossRef

16. Baumgardner DJ, Buggy BP, Mattson BJ, Burdick JS, Ludwig D. Epidemiology of blastomycosis in a region of high endemicity in north central Wisconsin. Clin Infect Dis. 1992;15:629-35. CrossRef

17. Baumgardner DJ, Burdick JS. An outbreak of human and canine blastomycosis. Rev Infect Dis. 1991;13:898-905. CrossRef

18. Centers for Disease Control and Prevention. Blastomycosis statistics. http://www.cdc.gov/fungal/diseases/blastomycosis/ statistics.html. Accessed December 29, 2015.

19. DiSalvo AF. The ecology of Blastomyces dermatitidis. In: AlDoory Y, DiSalvo AF (eds). Blastomycosis. New York, NY: Plenum, 1992, pp. 43-73.

20. Restrepo A, Baumgardner DJ, Bagagli E, et al. Clues to the presence of pathogenic fungi in certain environments. Med Mycol. 2000;38 Suppl 1:67-77. CrossRef

21. Baumgardner DJ. Microecology of Blastomyces dermatitidis: the ammonia hypothesis. Med Mycol. 2009;47:745-52. CrossRef

22. Baumgardner DJ, Laundre B. Studies on the molecular ecology of Blastomyces dermatitidis. Mycopathologia. 2000;152:51-8. CrossRef

23. Bruce Light R, Kralt D, Embil JM, et al. Seasonal variations in the clinical presentation of pulmonary and extrapulmonary blastomycosis. Med Mycol. 2008;46:835-41. CrossRef

24. Baumgardner DJ. Disease-causing fungi in homes and yards in the midwestern United States. J Patient Cent Res Rev. 2016;3:99-110.

25. Proctor RA. Infectious diseases in Wisconsin. WMJ. 1998;97:20-2.

26. Proctor RA. Blastomycosis is a serious disease, but let's not raise fears without conclusive data. WMJ. 2001;100:8-9, 34.

27. Bachir J, Fitch GL. Northern Wisconsin married couple infected with blastomycosis. WMJ. 2006;105:55-7.

28. Blondin N, Baumgardner DJ, Moore GE, Glickman LT. Blastomycosis in indoor cats: suburban Chicago, Illinois, USA. Mycopathologia. 2007;163:59-66. CrossRef

29. Baumgardner DJ, Paretsky DP. Blastomycosis: more evidence for exposure near one's domicile. WMJ. 2001;100:43-5.

30. Denton JF, DiSalvo AF. Additional isolations of Blastomyces dermatitidis from natural sites. Am J Trop Med Hyg. 1979;28:697-700.

31. Baumgardner DJ, Paretsky DP. The in vitro isolation of Blastomyces dermatitidis from a woodpile in north central Wisconsin, USA. Med Mycol. 1999;37:163-8. CrossRef

32. Wisconline. The eastern ridges and lowlands of Wisconsin. https://www.wisconline.com/wisconsin/geoprovinces/ easternridges.html. Accessed Sep. 28, 2015.
33. Center for Land Use Education. Wisconsin land use megatrends: forests (published 2005). https://www.uwsp.edu/ cnr-ap/clue/documents/megatrends/WiscForests-PDFwebStandard.pdf. Accessed September 28, 2015.

34. Vander Wyst KB, Kram JJ, Baumgardner DJ. Clinical approach to nonresponsive pneumonia in adults diagnosed by a primary care clinician: a retrospective study. J Patient Cent Res Rev. 2016;3:79-89.

35. Marrie TJ. Community-acquired pneumonia in the elderly. Clin Infect Dis. 2000;31:1066-78. CrossRef

36. Lutfiyya MN, Henly E, Chang LF, Reyburn SW. Diagnosis and treatment of community-acquired pneumonia. Am Fam Physician. 2006;73:442-50.

37. DiSalvo AF. The epidemiology of blastomycosis. In: AlDoory Y, DiSalvo AF (eds). Blastomycosis. New York, NY: Plenum, 1992, pp. 75-104.

38. Benedict K, Roy M, Chiller T, Davis JP. Epidemiologic and ecologic features of blastomycosis: a review. Curr Fungal Infect Rep. 2012;6:327-35. CrossRef

39. Khuu D, Shafir S, Bristow B, Sorvillo F. Blastomycosis mortality rates, United States, 1990-2010. Emerg Infect Dis. 2014;20:1789-94. CrossRef

40. Meece JK, Anderson JL, Gruszka S, Sloss BL, Sullivan B, Reed KD. Variation in clinical phenotype of human infection among genetic groups of Blastomyces dermatitidis. J Infect Dis. 2013;207:814-22. CrossRef

41. Reed KD, Meece JK, Archer JR, Peterson AT. Ecologic niche modeling of Blastomyces dermatiditis in Wisconsin. PLoS One. 2008;3:e2034. CrossRef

42. Choptiany M, Wiebe L, Limerick B, et al. Risk factors for acquisition of endemic blastomycosis. Can J Infect Dis Med Microbiol. 2009;20:117-21.

43. Harrell ER, Curtis AC. North American blastomycosis. Am J Med. 1959;27:750-66. CrossRef

44. Harrell ER, Curtis AC. The treatment of North American blastomycosis with amphotericin B. AMA Arch Derm. 1957;76:561-9. CrossRef

45. Jordan M, Martz S, Hollowell C. Cutaneous blastomycosis mimicking squamous cell carcinoma of the scrotum. Internet Journal of Urology. 2007;5(2):1-4.

46. Ololade IA. An assessment of heavy-metal contamination in soils within auto-mechanic workshops using enrichment and contamination factors with geoaccumulation indexes. $J$ Environ Protect. 2014;5:970-82. CrossRef

47. Risk Reduction Engineering Laboratory and Center for Environmental Research Information. Guides to Pollution Prevention: The Automobile Repair Industry. Cincinnati, $\mathrm{OH}$ : Office of Research and Development, U.S. Environmental Protection Agency, October 1991.

48. Shayler H, McBride M, Harrison E. Sources and impacts of contaminants in soils. Ithaca, NY: Cornell Waste Management Institute, April 15, 2009.

(C) 2016 Aurora Health Care, Inc. 